\title{
Agronomic response of cauliflower to the addition of silicon to the soil under water deficit ${ }^{1}$
}

\author{
Gustavo Soares Wenneck ${ }^{2}$, Reni Saath ${ }^{2}$, Roberto Rezende ${ }^{2}$, \\ André Felipe Barion Alves Andrean², Danilo César Santi ${ }^{2}$
}

\section{ABSTRACT}

Water deficit in cauliflower cultivation may impair its development and yield. This study aimed to analyze the agronomic performance of cauliflower grown in a protected environment, under different water conditions and silicon ( $\mathrm{Si}$ ) doses. The experiment was arranged in a randomized block design, in a $3 \times 4$ factorial scheme, with three levels of water replacement $[40,70$ and $100 \%$ of the evapotranspiration (ETc)] and four Si doses (0, 50, 100 and $\left.150 \mathrm{~kg} \mathrm{ha}^{-1}\right)$, with four replications. Leaf (SPAD index, area, fresh and dry weight), stem (diameter, height, fresh and dry weight) and inflorescence (diameter, fresh weight, dry weight, water content and commercial classification) characteristics were evaluated. The replacement of $40 \%$ of the ETc showed lower results for the SPAD index in the phases II and III, leaf area, leaf and stem fresh weight and inflorescence diameter. The $70 \%$ replacement cultivation showed a yield similar to that of the $100 \%$ of the ETc. The use of Si was beneficial for the productive performance of the cauliflower at all levels of water replacement.

KEYWORDS: Brassica oleracea var. botrytis, water stress, irrigation management.

\section{INTRODUCTION}

Cauliflower (Brassica oleracea var. botrytis) has economic relevance among brassicas due to the marketable immature inflorescence, mainly for family farming (May et al. 2007, Oliveira et al. 2018). Due to the edaphoclimatic requirements of the crop, especially in mild temperatures, cultivars and management practices enable the production in mid-season and summer (Cardoso \& Silva 2009, Oliveira et al. 2018, Pereira et al. 2018).

Cultivation under controlled water deficit, a practice adopted in several crops, including cauliflower, allows satisfactory production levels

\section{RESUMO}

Resposta agronômica de couve-flor à adição de silício ao solo sob estresse hídrico

O déficit hídrico no cultivo pode prejudicar o desenvolvimento e a produtividade da couve-flor. Objetivou-se analisar o desempenho agronômico de couve-flor cultivada em ambiente protegido, em diferentes condições hídricas e doses de silício (Si). Utilizou-se delineamento em blocos ao acaso, em esquema fatorial $3 \times 4$, sendo três níveis de reposição hídrica [40, 70 e $100 \%$ da evapotranspiração (ETc)] e quatro doses de $\mathrm{Si}(0$, 50,100 e $150 \mathrm{~kg} \mathrm{ha}^{-1}$ ), com quatro repetições. Foram avaliadas características das folhas (índice SPAD, área, massa fresca e seca), do caule (diâmetro, altura, massa fresca e seca) e da inflorescência (diâmetro, massa fresca, massa seca, teor de água e classificação comercial). A reposição de $40 \%$ da ETc apresentou menores resultados para o índice SPAD nas fases II e III, área foliar, massa fresca das folhas e do caule e diâmetro da inflorescência. O cultivo com reposição de $70 \%$ apresentou produtividade semelhante à de $100 \%$ da ETc. A utilização do Si foi benéfica para o desempenho produtivo da couve-flor em todos os níveis de reposição hídrica.

PALAVRAS-CHAVE: Brassica oleracea var. botrytis, estresse hídrico, manejo da irrigação.

and increases the resource use efficiency (Sohail et al. 2018, Hachmann et al. 2019). However, the occurrence of water deficit exposes the plant to stress, with variable morphological, physiological and yield responses, depending on the intensity of the deficit and the associated management (Vieira et al. 2014, Souza et al. 2015, Ferreira et al. 2019).

The use of silicon $(\mathrm{Si})$ in vegetables grown under water deficit is promising, considering the beneficial effects on plants in unfavorable physical-chemical soil conditions, with the increase in the physical resistance of the plant tissue and the metabolic production (Souza et al. 2015, Weerahewa \& Somapala 2016, Jadhao et al. 2020).

\footnotetext{
${ }^{1}$ Received: Dec. 06, 2020. Accepted: Mar. 11, 2021. Published: Apr. 19, 2021. DOI: 10.1590/1983-40632021v5166908.

${ }^{2}$ Universidade Estadual de Maringá, Departamento de Agronomia, Maringá, PR, Brasil.E-mail/ORCID: gustavowenneck@gmail.com/ 0000-0002-4151-2358; rsaath@uem.br/0000-0002-6610-2873; rrezende@uem.br/0000-0002-6213-1845; andre_andrian@hotmail.com/0000-0003-3403-2951; danilosantiagro@gmail.com/0000-0003-2626-5667.
} 
The Si supply allows to alleviate the stress condition and improve the crop performance, increasing the yield and post-harvest quality in conditions of water deficit and $\mathrm{N}$ toxicity (Barreto et al. 2017, Lozano et al. 2018, Nunes et al. 2019), with the fertilization being justified by the low concentration of the element in tropical soils (Malavolta 2006, Menegale et al. 2015).

Therefore, this study aimed to analyze the effect of Si doses on the yield performance of cauliflower (Brassica oleracea var. botrytis) grown in a protected environment with different water replacement levels.

\section{MATERIAL AND METHODS}

The study was carried out in a protected environment ( $23^{\circ} 25^{\prime} \mathrm{S}, 51^{\circ} 57^{\prime} \mathrm{W}$ and $542 \mathrm{~m}$ of altitude) of the Universidade Estadual de Maringá, in Maringá, Paraná state, Brazil. The cultivation was carried out from October 14, 2019, to February 13, 2020, being monitored the conditions of temperature and relative humidity of the ambient air (Figure 1), using a weather station installed in the protected environment.

A randomized block design was used, in a $3 \times 4$ factorial scheme, with three levels of water replacement [40, 70 and $100 \%$ of the evapotranspiration (ETc)] and four Si doses $(0,50$, 100 and $\left.150 \mathrm{~kg} \mathrm{ha}^{-1}\right)$, with four replications.

Sharon hybrid seedlings, produced in expanded polystyrene trays of 128 cells containing the commercial substrate MecPlant $^{\mathrm{TM}}$, were transplanted at 35 days after sowing, adopting the spacing of
$0.5 \mathrm{~m}$ between plants. The experimental units were composed of 48 seedbeds $(3.0 \times 0.5 \mathrm{~m})$ with six plants each, and the useful portion consisted of the three central plants.

The experiment was installed in a Nitossolo Vermelho Distroférrico, corresponding to a Ultisol in the soil taxonomy classification (Santos et al. 2018), consisting of clay (72\%), silt (6\%), fine sand (7\%), coarse sand $(5 \%)$ and bulk density of $1.09 \mathrm{t} \mathrm{m}^{-3}$. The soil chemical analysis had the following results: $\mathrm{pH}\left(\mathrm{CaCl}_{2}\right): 6.7$; $\mathrm{pH}$ (SMP): 7.1; aluminum: $0 \mathrm{cmol}_{\mathrm{c}} \mathrm{dm}^{-3}$; hydrogen: $2.17 \mathrm{cmol}_{\mathrm{c}} \mathrm{dm}^{-3}$; calcium: $12.31 \mathrm{cmol}_{\mathrm{c}} \mathrm{dm}^{-3}$; magnesium: $2.70 \mathrm{cmol}_{\mathrm{c}} \mathrm{dm}^{-3}$; potassium: $0.92 \mathrm{cmol}_{\mathrm{c}} \mathrm{dm}^{-3}$; cation exchange capacity (pH 7.0): $18.10 \mathrm{cmol} \mathrm{dm}_{\mathrm{c}}^{-3}$; effective cation exchange capacity: $15.93 \mathrm{cmol}_{\mathrm{c}} \mathrm{dm}^{-3}$; organic matter: $1.99 \%$; phosphorus (Mehlich-I): $98.88 \mathrm{mg} \mathrm{dm}^{-3}$; remaining phosphorus: $18.96 \mathrm{mg} \mathrm{dm}^{-3}$; sulfur: $129.70 \mathrm{mg} \mathrm{dm}^{-3}$; boron: $0.06 \mathrm{mg} \mathrm{dm}^{-3}$; copper: $14.70 \mathrm{mg} \mathrm{dm}^{-3}$; iron: $71.16 \mathrm{mg} \mathrm{dm}^{-3}$; manganese: $150.18 \mathrm{mg} \mathrm{dm}^{-3}$; zinc: $9.66 \mathrm{mg} \mathrm{dm}^{-3}$; and silicon $\left(\mathrm{CaCl}_{2} 0.01 \mathrm{~mol} \mathrm{dm}^{-3}\right)$ : $15.70 \mathrm{mg} \mathrm{dm}^{-3}$. When preparing the seedbeds, the soil surface layer $(0-0.3 \mathrm{~m})$ was turned over with the help of a cultivator.

To adequately supply the nutritional demand of the plants, before transplanting the seedlings, $30 \mathrm{~kg} \mathrm{ha}^{-1}$ of $\mathrm{N}$ (urea), $250 \mathrm{~kg} \mathrm{ha}^{-1}$ of $\mathrm{P}_{2} \mathrm{O}_{5}$ (simple superphosphate), $100 \mathrm{~kg} \mathrm{ha}^{-1}$ of $\mathrm{K}_{2} \mathrm{O}$ (potassium chloride) and $4 \mathrm{~kg} \mathrm{ha}^{-1}$ of $\mathrm{B}$ (boric acid) were incorporated, following the recommendations for the Paraná state (Pauletti \& Motta 2017).

The water depths of evapotranspiration replacement were determined using three lysimeters

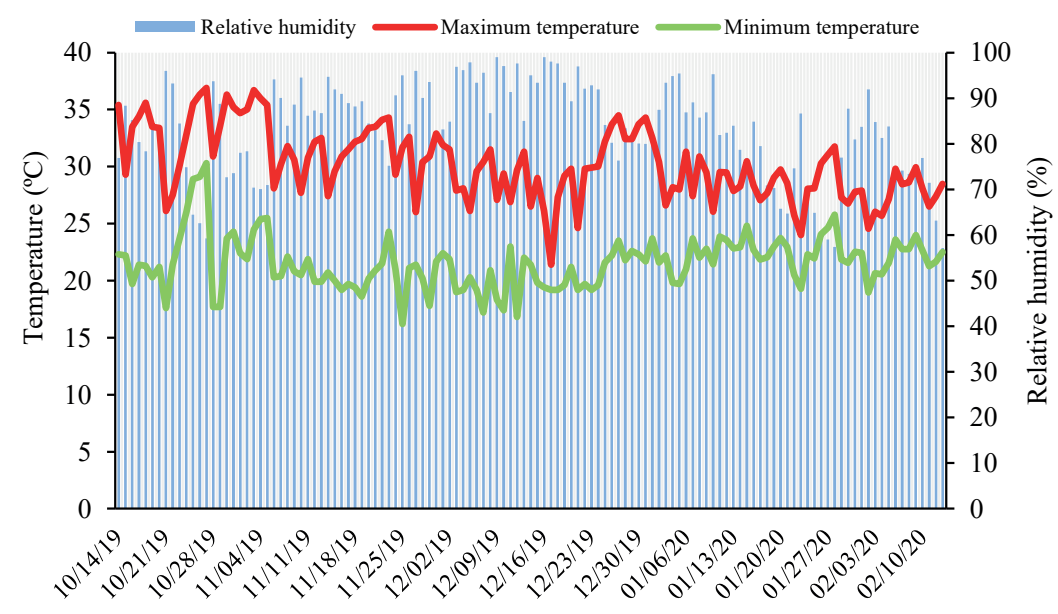

Figure 1. Maximum and minimum temperature and relative air humidity inside the protected environment (Maringá, Paraná state, Brazil, 2019/2020). 
of the constant water table with compensation installed inside the protected environment, with daily readings and determinations. Tensiometers were installed in the seedbeds at depths of 5 and $15 \mathrm{~cm}$, and the water replacement was performed when the average soil water tension in the plots with $100 \%$ of daily ETc replacement presented values close to $30 \mathrm{kPa}$ (Marouelli 2008), with readings taken in the morning, with a digital tensiometer.

The irrigation system consisted of drippers spaced $0.25 \mathrm{~m}$ apart, with an average flow of $5 \mathrm{~L} \mathrm{~h}^{-1}$ and inlet pressure of $20 \mathrm{mca}$, with one distribution line per site. It presented a Christiansen's uniformity coefficient of $94 \%$, statistical uniformity coefficient of $94.98 \%$ and distribution uniformity coefficient of $92.89 \%$.

The water used for irrigation, coming from a semi-artesian well, had a clear appearance, with no odor, apparent color $<0.2$ (Hazen unit), turbidity of 0.38 (turbidity unit), $\mathrm{pH}$ of 7.78 , conductivity of $158.55 \mu \mathrm{S} \mathrm{cm}^{-1}$, total hardness $\left(\mathrm{CaCO}_{3}\right)$ of $48.85 \mathrm{mg} \mathrm{L}^{-1}$, calcium hardness of $36.30 \mathrm{mg} \mathrm{L}^{-1}$, magnesium hardness of $12.55 \mathrm{mg} \mathrm{L}^{-1}$ and dissolved silica $\left(\mathrm{SiO}_{2}\right)$ of $45.94 \mathrm{mg} \mathrm{L}^{-1}$.

During the seven days after transplantation (DAT), considered as the seedling establishment period, the soil moisture was kept (tension $<20 \mathrm{kPa}$ ). At the eighth DAT, the irrigation management was differentiated, according to the tested levels of water replacement.

The application of $\mathrm{Si}$, using the commercial product AgriSil $^{\text {TM }}\left(98 \%\right.$ of $\mathrm{SiO}_{2}$ ) in the form of wettable powder, was carried out with doses $(0,50$, 100 and $150 \mathrm{~kg} \mathrm{ha}^{-1}$ ) divided into three applications, in each development phase. For this, the cycle was subdivided into three phases, according to Allen et al. (1998): phase I (initial stage) from the transplant to plants with 7-10 leaves; phase II (intermediate stage) from 7-10 leaves to when inflorescence in the meristem occurs; phase III (final stage) from the presence of inflorescence to the harvest. Fertilization with Si was performed by diluting the product in water (2 L) and applying it over the soil surface with a manual watering can, with subsequent irrigation as replacement of evapotranspiration, and a decrease of $2 \mathrm{~L}$ in the replacement volume in each seedbed.

At each stage of the crop development, the SPAD index was determined with a SPAD-502 Plus ${ }^{\text {TM }}$ meter, performing the reading in fully expanded leaves (three leaves per plant) of the upper third, between 8:00 a.m. and 9:00 a.m. At harvest, in each plant, the following was evaluated: number of leaves; leaf area, with a LI-COR ${ }^{\mathrm{TM}}$ equipment (LI 3100 model); dimensions of the stem (diameter and height) and inflorescence (diameter and thickness), with a digital caliper $( \pm 0.1 \mathrm{~mm})$; fresh matter of leaves, stem and inflorescence, with an analytical scale $( \pm 0.01 \mathrm{~mm})$; dry matter of leaves and stem, in an air circulation oven at $105{ }^{\circ} \mathrm{C}$, for $24 \mathrm{~h}$; water content of the inflorescence, due to the difference in the fresh and dry matter; and the commercial classification (HortiBrasil 2011), considering absolute mean values of the largest proportion ( $>50 \%$ ) of the inflorescences.

The data were submitted to analysis of variance and the $\mathrm{F}$ test, regression analysis was performed for doses, and, for water replacement levels, the split was made for each Si dose, with the averages compared by the Tukey test at $5 \%$ of significance, using the Sisvar software (Ferreira 2019).

\section{RESULTS AND DISCUSSION}

Water availability affects the plant metabolism, whose dynamics directly correlate with chlorophyll and leaf temperature (Silva et al. 2015). According to Taiz et al. (2017), the reduction of photosynthesis occurs in response to conditions of more severe water deficit, when the availability of water is no longer sufficient to supply the metabolism of plants, resulting in less mass flow and absorption of nutrients (Barreto et al. 2017). In the phase I of the cauliflower development, the response of the SPAD index was not significant $(\mathrm{p}>0.05)$ for the amount of Si applied in the water replacements of $40 \%$ and $100 \%$ of the ETc (Figure 2A).

In the phases II and III (Figures 2B and $2 \mathrm{C}$, respectively), the $\mathrm{Si}$ application increased, in different proportions, the SPAD index, with a greater variation between the water replacement levels during the development of the crop, associated with the development of the leaf area, distribution of photoassimilates and source/sink ratio, mainly in the development of the inflorescence. In the cultivation of white oats, the irrigation management changed the SPAD index when submitted to $74.3 \%$ of the ETc replacement (Coelho et al. 2018). For the different stages of plant development, the Si application showed a significant effect, at least at the water replacement level, which is related to the increasing 

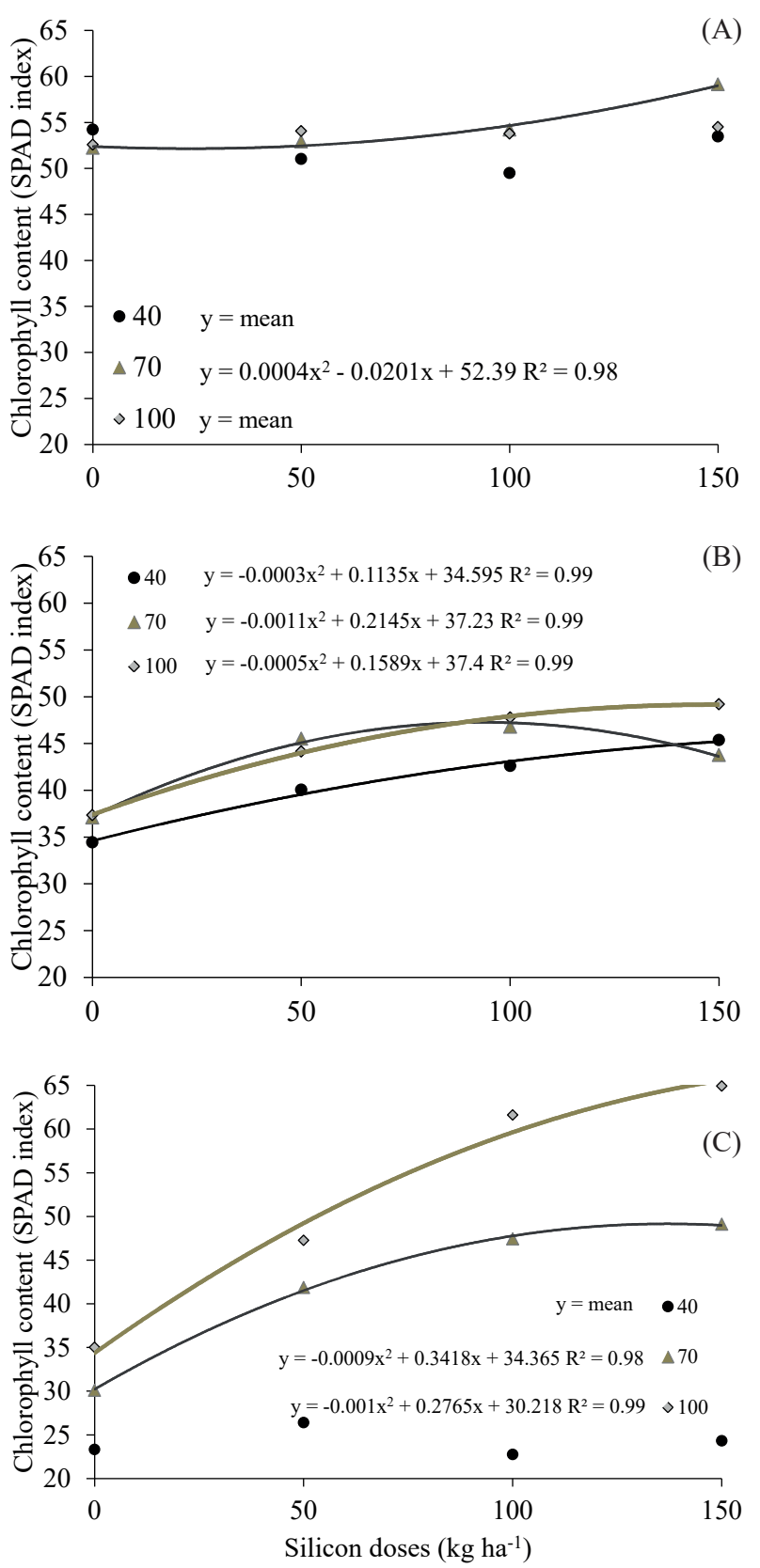

Figure 2. SPAD index at different development stages of the cauliflower (Brassica oleraceae var. botrytis) plants, with different silicon doses and water replacement levels. A) Phase I; B) Phase II; C) Phase III.

amount of Si applied, increasing the availability for the plant (Table 1).

In plants, the activities related to forming a double layer of silicate in the leaf tissue reduce the water loss, maintain the water potential and prevent the breakdown of proteins, conserving the photosynthetic activity (Souza et al. 2015). There was no significant response in the phase I between the adopted levels of water replacement, possibly associated with a low evapotranspiration in the initial development, reducing the cumulative effect of water deficit. In the phase II, similarly to the other water conditions, the replacement of $40 \%$ of the ETc and the application of $150 \mathrm{~kg} \mathrm{ha}^{-1}$ of Si increased the SPAD index (Figure 2), possibly reflecting the improvement in the efficiency of physiological processes related to photosynthesis (Epstein \& Bloom 2006).

In the phase III, within each silicon dose, the increase in the water replacement implied an increase in the SPAD index (Table 1). According to Vieira et al. (2014), the increase in the level of water replacement up to $100 \%$ of the ETc causes increases in the chlorophyll content; however, the excess of water reduces the oxygen in the root zone, promoting a decrease in the levels of chlorophyll in the leaves. The increase in water replacement also increases the chlorophyll fluorescence, reduces the leaf temperature and alters the carotenoid levels (Silva et al. 2015, Silva et al. 2020).

For the Si application, an increase in the stem matter was obtained for the adopted amounts, mainly in the lowest level of water replacement ( $40 \%$ of the ETc), as shown in Figure 3, the increment being represented by quadratic models.

The irrigation management can also influence plant morphological components, such as roots, stem, leaves and fruits (Marouelli 2008). The stem diameter is associated with the support capacity, translocation of metabolites and yield (Torres et al. 2014). However, for the analyzed conditions, there was no significant difference $(\mathrm{p}>0.05)$ for the stem diameter and height depending on the application of $\mathrm{Si}$ and water conditions (Table 2).

Regarding the water replacement levels, the stem fresh and dry matter in the condition of $40 \%$ of the ETc were significantly lower in all Si doses, considering that there is a high deficit $(60 \%)$ that impacts the morphological development. For $70 \%$ of the ETc, with Si application, there was no significant difference for fresh matter, concerning the condition without water deficit ( $100 \%$ of the ETc), in the doses of 50,100 and $150 \mathrm{~kg} \mathrm{ha}^{-1}$ of Si, while, for dry matter with $\mathrm{Si}$ application greater than $50 \mathrm{~kg} \mathrm{ha}^{-1}$, the results were lower (Table 2).

The matter accumulation and leaf development were increased by the increase in the Si doses, with different degrees of response at the replacement level and component analyzed (Figure 4). The element 
Table 1. Breakdown of the SPAD index at different development stages of the cauliflower (Brassica oleracea var. botrytis), with different silicon doses and water replacement levels.

\begin{tabular}{|c|c|c|c|c|}
\hline Silicon $\left(\mathrm{kg} \mathrm{ha}^{-1}\right)$ & Water replacement level (\% ETc) & Phase I & Phase II & Phase III \\
\hline \multirow{3}{*}{ 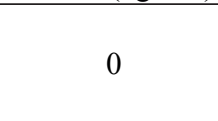 } & 40 & $54.23^{\mathrm{ns}}$ & $34.43 \mathrm{~b}$ & $23.32 \mathrm{c}$ \\
\hline & 70 & 52.24 & $37.09 \mathrm{a}$ & $30.10 \mathrm{~b}$ \\
\hline & 100 & 52.59 & $37.35 \mathrm{a}$ & $35.02 \mathrm{a}$ \\
\hline \multirow{3}{*}{50} & 40 & 51.04 & $40.05 \mathrm{~b}$ & $26.40 \mathrm{c}$ \\
\hline & 70 & 52.90 & $45.51 \mathrm{a}$ & $41.87 \mathrm{~b}$ \\
\hline & 100 & 54.06 & $44.15 \mathrm{a}$ & $47.26 \mathrm{a}$ \\
\hline \multirow{3}{*}{100} & 40 & 49.50 & $42.60 \mathrm{~b}$ & $22.75 \mathrm{c}$ \\
\hline & 70 & 54.20 & $46.80 \mathrm{a}$ & $47.42 \mathrm{~b}$ \\
\hline & 100 & 53.79 & $47.77 \mathrm{a}$ & $61.60 \mathrm{a}$ \\
\hline \multirow{3}{*}{150} & 40 & 53.48 & $45.37 \mathrm{a}$ & $24.31 \mathrm{c}$ \\
\hline & 70 & 59.13 & $43.76 \mathrm{a}$ & $49.10 \mathrm{~b}$ \\
\hline & 100 & 54.51 & $49.20 \mathrm{a}$ & $64.93 \mathrm{a}$ \\
\hline \multicolumn{2}{|c|}{ Coefficient of variation (\%) } & 8.86 & 17.75 & 18.30 \\
\hline
\end{tabular}

* Means with equal letters do not differ from each other by the Tukey test at $5 \%$ of significance. ${ }^{\text {ns }}$ Not significant at $5 \%$ of probability.

Table 2. Breakdown of morphological variables of the cauliflower (Brassica oleracea var. botrytis) stems, with different silicon doses and water replacement levels.

\begin{tabular}{|c|c|c|c|c|c|}
\hline $\begin{array}{l}\text { Silicon } \\
\left(\mathrm{kg} \mathrm{ha}^{-1}\right)\end{array}$ & $\begin{array}{l}\text { Water replacement level } \\
(\% \text { ETc })\end{array}$ & $\begin{array}{l}\text { Diameter } \\
(\mathrm{mm})\end{array}$ & $\begin{array}{l}\text { Height } \\
(\mathrm{cm})\end{array}$ & Fresh mass & Dry mass \\
\hline \multirow{3}{*}{0} & 40 & $33.98^{\mathrm{ns}}$ & $27.90^{\text {ns }}$ & $124.88 \mathrm{c}$ & $24.26 \mathrm{~b}$ \\
\hline & 70 & 34.95 & 26.66 & $188.68 \mathrm{~b}$ & $37.15 \mathrm{a}$ \\
\hline & 100 & 32.15 & 27.25 & $244.94 \mathrm{a}$ & $37.00 \mathrm{a}$ \\
\hline \multirow{3}{*}{50} & 40 & 33.22 & 28.30 & $140.73 \mathrm{~b}$ & $36.03 \mathrm{~b}$ \\
\hline & 70 & 37.89 & 28.50 & $214.43 \mathrm{a}$ & $40.88 \mathrm{a}$ \\
\hline & 100 & 32.20 & 26.25 & $243.44 \mathrm{a}$ & $43.41 \mathrm{a}$ \\
\hline \multirow{3}{*}{100} & 40 & 36.17 & 32.40 & $143.05 \mathrm{~b}$ & $36.39 \mathrm{~b}$ \\
\hline & 70 & 31.32 & 28.80 & $220.25 \mathrm{a}$ & $36.76 \mathrm{~b}$ \\
\hline & 100 & 33.16 & 21.58 & $251.70 \mathrm{a}$ & $40.62 \mathrm{a}$ \\
\hline \multirow{3}{*}{150} & 40 & 35.61 & 30.50 & $171.00 \mathrm{~b}$ & $42.95 \mathrm{~b}$ \\
\hline & 70 & 34.21 & 27.44 & $225.24 \mathrm{a}$ & $40.21 \mathrm{~b}$ \\
\hline & 100 & 33.70 & 29.16 & $265.24 \mathrm{a}$ & $46.11 \mathrm{a}$ \\
\hline \multicolumn{2}{|c|}{ Coefficient of variation (\%) } & 18.99 & 16.66 & 15.71 & 20.18 \\
\hline
\end{tabular}

* Means with equal letters do not differ from each other by the Tukey test at $5 \%$ of significance. ${ }^{\text {ns }}$ Not significant at $5 \%$ of probability.

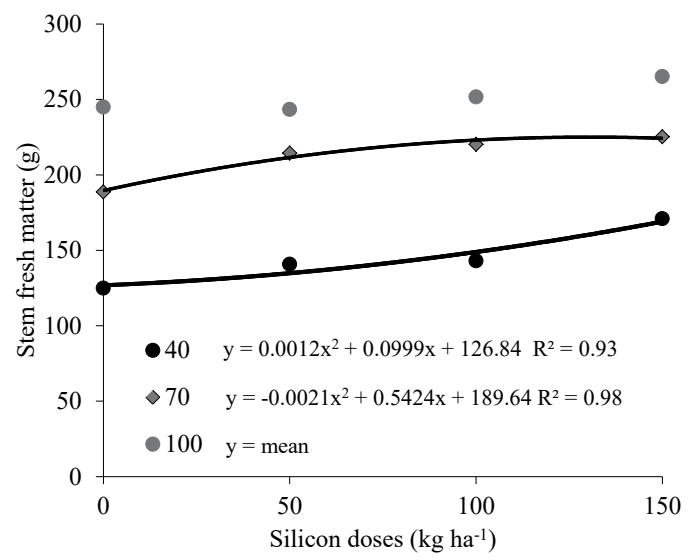

(A)

Figure 3. Stem fresh (A) and dry (B) matter accumulation in the cauliflower (Brassica oleraceae var. botrytis) plants, with different silicon doses and water replacement levels. 

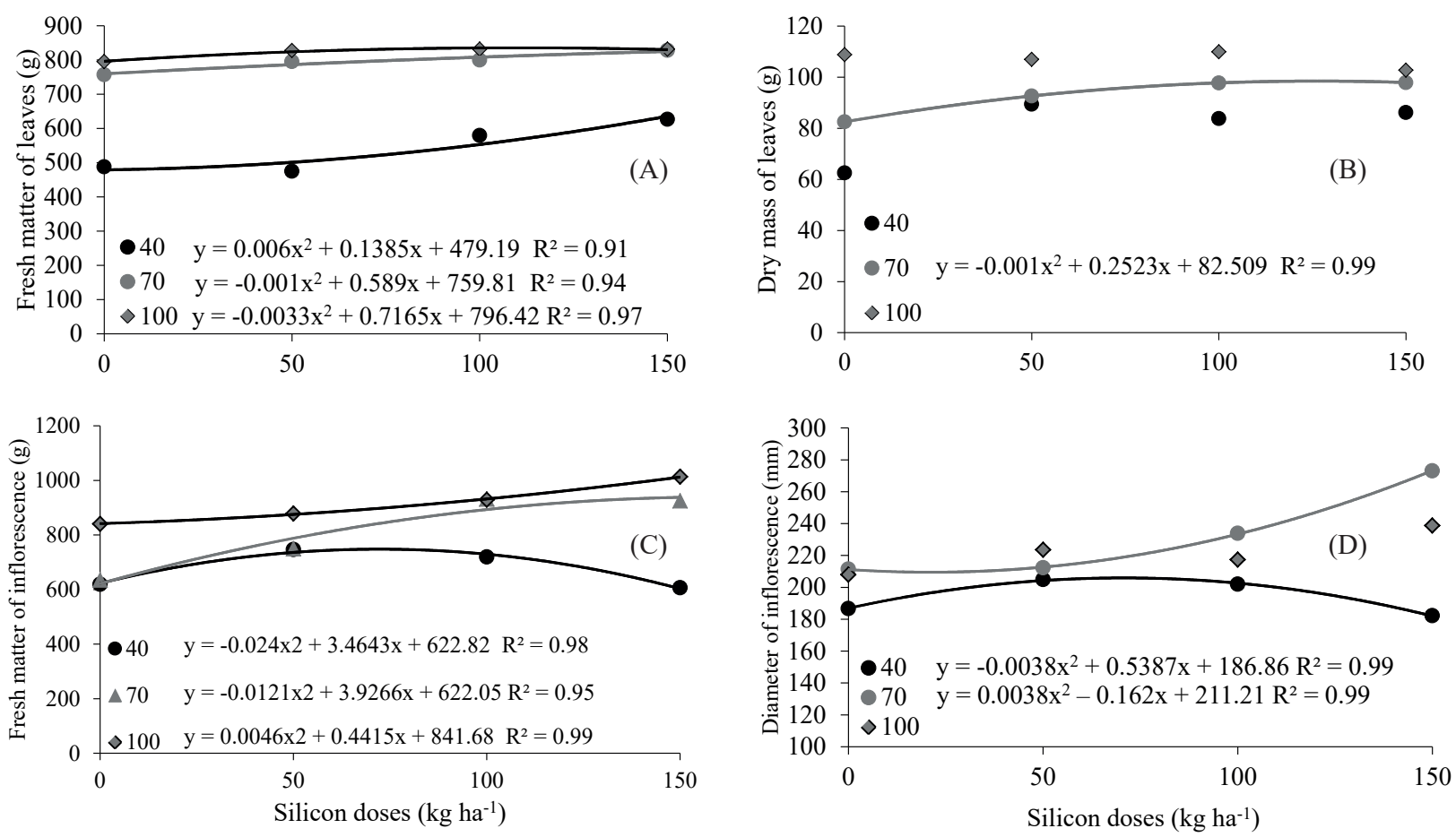

Figure 4. Leaf fresh (A) and dry (B) matter, inflorescence fresh matter (C) and diameter (D) of the cauliflower (Brassica oleraceae var. botrytis) plants, with different silicon doses and water replacement levels.

also increased the leaf area and accumulation of dry matter in sprouts and roots of cauliflower under stress due to the use of ammonium (Barreto et al. 2017).

In the present study, the number of leaves, in the condition of $40 \%$ of replacement of the ETc with doses of 0,50 and $150 \mathrm{~kg} \mathrm{ha}^{-1}$, was lower than for the other conditions (Table 3), diverging from the results obtained by Curvelo et al. (2019), using foliar application with the effect of $\mathrm{Si}$ associated with the form and time of application.

Considering the condition with no $\mathrm{Si}$ application, the different irrigation levels influenced the accumulation and leaf development, corroborating the results by Shams \& Farag (2019), who, in the condition of $70 \%$ of the total irrigation, observed a high reduction of growth and yield parameters in cauliflower.

The complex interactions between intrinsic and environmental factors can act in opposite directions. In hot and dry environments, the low concentration of $\mathrm{CO}_{2}$ and the high irradiance directly stimulate the opening of the stomata, while the low humidity and excessive transpiration cause the stomata closure (Costa \& Marenco 2007).

For the cultivation of the Sharon cauliflower cultivar under field conditions, with sprinkler irrigation, Oliveira et al. (2018) observed that the inflorescences presented a fresh matter of $895.31 \mathrm{~g}$ and diameter of $216 \mathrm{~mm}$ at the harvest, values similar or close to the results obtained in the present study (Figure 4C), whose cultivation occurred in a period of unfavorable climatic conditions for the crop (May et al. 2007).

In conditions of water deficit, the absorption of nutrients is affected (Souza et al. 2019), especially during the development of the cauliflower inflorescence, when there is a greater nutritional demand (Alves et al. 2011). Combined with the development of other morphological components, production and translocation of metabolic and climatic conditions, there is an influence on the development and formation of the cauliflower inflorescence (May et al. 2007). There was a significant effect due to the water replacement levels and Si doses on the fresh matter and inflorescence diameter (Table 3).

Under water restrictions, the yield of the cauliflower plants was proportional to the increase in the Si amount added to the soil, except at the dose of $150 \mathrm{~kg} \mathrm{ha}^{-1}$ and water replacement of $40 \%$ of the ETc (Table 4). With no influence on yield, the potassium silicate via leaf favored the post-harvest inflorescence (Curvelo et al. 2019). 
Coupled with yield (fresh matter), the inflorescence diameter may present a product appreciation character, when adopting product classification parameters. According to HortiBrasil (2011), larger diameters fit the upper classes, while visual defects may reduce the product category. In the conditions of $70 \%$ and $100 \%$ of the ETc, the use of Si increased the commercial quality for the doses of 100 and $150 \mathrm{~kg} \mathrm{ha}^{-1}$, and, under the condition of $40 \%$ of the ETc, with the application of 50 and $100 \mathrm{~kg} \mathrm{ha}^{-1}$, the class was superior to the treatment without fertilization with $\mathrm{Si}$ and with fertilization of
$150 \mathrm{~kg} \mathrm{ha}^{-1}$; however, the classes were inferior to the other water replacement conditions (Figure 4).

The conditions did not influence the water content of the product at harvest (Table 4). Considering the inflorescence as the main sink in the final stage, water and nutrients are redistributed, mainly from the older leaves (lower third) to the reproductive organ. The inflorescences were classified as category I (HortiBrasil 2011), with cream color and slight defects, when present. The Si fertilization benefited the increase of commercial characteristics (Figure 5). Similarly to the fertility management

Table 3. Breakdown of morphological variables of the cauliflower (Brassica oleracea var. botrytis) leaves, with different silicon doses and water replacement levels.

\begin{tabular}{|c|c|c|c|c|c|}
\hline \multirow{2}{*}{$\begin{array}{l}\text { Silicon } \\
\left(\mathrm{kg} \mathrm{ha}^{-1}\right)\end{array}$} & \multirow{2}{*}{$\begin{array}{l}\text { Water replacement level } \\
\qquad(\% \mathrm{ETc})\end{array}$} & \multirow[b]{2}{*}{ Leaves plant ${ }^{-1}$} & \multicolumn{2}{|c|}{ Matter } & \multirow{2}{*}{$\begin{array}{c}\text { Leaf area } \\
\mathrm{mm}^{2}\end{array}$} \\
\hline & & & fresh & dry & \\
\hline \multirow{3}{*}{0} & 40 & $17.00 \mathrm{~b}$ & $487.88 \mathrm{~b}$ & $62.50 \mathrm{c}$ & $4,753.02 \mathrm{c}$ \\
\hline & 70 & $22.00 \mathrm{a}$ & $756.96 \mathrm{a}$ & $82.51 \mathrm{~b}$ & $5,221.43 \mathrm{~b}$ \\
\hline & 100 & $20.50 \mathrm{a}$ & $795.26 \mathrm{a}$ & $108.85 \mathrm{a}$ & $6,849.19 \mathrm{a}$ \\
\hline \multirow{3}{*}{50} & 40 & $17.83 \mathrm{~b}$ & $475.13 b$ & $89.43 \mathrm{~b}$ & $6,420.54 \mathrm{~b}$ \\
\hline & 70 & $23.20 \mathrm{a}$ & $795.26 \mathrm{a}$ & $92.62 \mathrm{~b}$ & $7,006.23 \mathrm{a}$ \\
\hline & 100 & $22.83 \mathrm{a}$ & $827.56 \mathrm{a}$ & $106.98 \mathrm{a}$ & $6,925.74 \mathrm{a}$ \\
\hline \multirow{3}{*}{100} & 40 & $22.00 \mathrm{a}$ & $579.45 \mathrm{~b}$ & $83.81 \mathrm{~b}$ & $6,004.48 \mathrm{~b}$ \\
\hline & 70 & $22.80 \mathrm{a}$ & $799.96 \mathrm{a}$ & $97.74 \mathrm{a}$ & $7,599.54 \mathrm{a}$ \\
\hline & 100 & $21.83 \mathrm{a}$ & $831.96 \mathrm{a}$ & $109.94 \mathrm{a}$ & $7,651.54 \mathrm{a}$ \\
\hline \multirow{3}{*}{150} & 40 & $19.40 \mathrm{~b}$ & $627.04 \mathrm{~b}$ & $86.20 \mathrm{~b}$ & $6,073.93 \mathrm{c}$ \\
\hline & 70 & $23.20 \mathrm{a}$ & $828.06 \mathrm{a}$ & $97.85 \mathrm{a}$ & $7,050.65 \mathrm{~b}$ \\
\hline & 100 & $26.00 \mathrm{a}$ & $831.63 \mathrm{a}$ & $102.74 \mathrm{a}$ & $8,627.49 \mathrm{a}$ \\
\hline \multicolumn{2}{|c|}{ Coefficient of variation $(\%)$} & 23.68 & 38.18 & 16.78 & 18.42 \\
\hline
\end{tabular}

* Means followed by equal letters do not differ by the Tukey test at $5 \%$ of probability.

Table 4. Breakdown of inflorescence variables of the cauliflower (Brassica oleracea var. botrytis), with different silicon doses and water replacement levels.

\begin{tabular}{|c|c|c|c|c|}
\hline \multirow{2}{*}{$\begin{array}{l}\text { Silicon } \\
\left(\mathrm{kg} \mathrm{ha}^{-1}\right)\end{array}$} & \multirow{2}{*}{$\begin{array}{c}\text { Water replacement level } \\
(\% \text { ETc })\end{array}$} & \multicolumn{3}{|c|}{ Inflorescence } \\
\hline & & Fresh matter $(\mathrm{g})$ & Diameter $(\mathrm{mm})$ & Water content $(\% \mathrm{wb})$ \\
\hline \multirow{3}{*}{0} & 40 & $619.34 \mathrm{~b}$ & $186.64 \mathrm{~b}$ & $90.94^{\mathrm{ns}}$ \\
\hline & 70 & $634.90 \mathrm{~b}$ & $211.36 \mathrm{a}$ & 89.97 \\
\hline & 100 & $840.63 \mathrm{a}$ & $207.94 \mathrm{a}$ & 90.15 \\
\hline \multirow{3}{*}{50} & 40 & $746.55 \mathrm{~b}$ & $204.95 \mathrm{~b}$ & 91.44 \\
\hline & 70 & $749.47 \mathrm{~b}$ & $212.24 \mathrm{ab}$ & 90.91 \\
\hline & 100 & $878.48 \mathrm{a}$ & $223.58 \mathrm{a}$ & 90.92 \\
\hline \multirow{3}{*}{100} & 40 & $719.09 \mathrm{~b}$ & $201.98 \mathrm{~b}$ & 90.41 \\
\hline & 70 & $931.87 \mathrm{a}$ & $233.83 \mathrm{a}$ & 89.77 \\
\hline & 100 & $929.01 \mathrm{a}$ & $217.38 \mathrm{a}$ & 91.26 \\
\hline \multirow{3}{*}{150} & 40 & $606.58 \mathrm{~b}$ & $182.21 \mathrm{~b}$ & 90.46 \\
\hline & 70 & $925.04 \mathrm{a}$ & $273.08 \mathrm{a}$ & 90.53 \\
\hline & 100 & $1,013.19 \mathrm{a}$ & $238.76 \mathrm{a}$ & 91.38 \\
\hline \multicolumn{2}{|c|}{ Coefficient of variation (\%) } & 17.52 & 4.30 & 1.24 \\
\hline
\end{tabular}




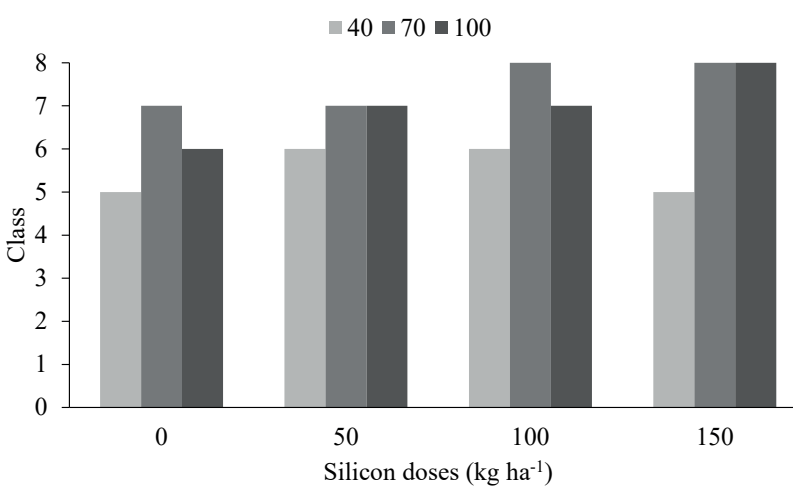

Figure 5. Commercial classification of the cauliflower (Brassica oleraceae var. botrytis) inflorescences, with different silicon doses and water replacement levels.

practices, they tend to impact the economic return of the crop.

Similarly to the improvements in the agronomic quality of melon (Lozano et al. 2018) and cauliflower (Curvelo et al. 2019), the agronomic performance of cauliflower under a deficit of up to $30 \%$ of the ETc showed a morphological development and yield similar to plants without water deficit (100\% of the ETc), associated with the performance of $\mathrm{Si}$ added to the soil, with an initial content of $15.70 \mathrm{mg} \mathrm{dm}^{-3}$. Based on the obtained results, new studies should address different water deficit intervals and investigate the performance in an environment of stress and interaction between different Si sources.

\section{CONCLUSIONS}

1. The yield performance of cauliflower under water replacement of $70 \%$ of the ETc is similar to plants without water restriction $(100 \%$ of the ETc). The replacement of $40 \%$ of the ETc limits the morphological and physiological variables of the crop, harming the matter accumulation and inflorescence yield.

2. The use of $\mathrm{Si}$ is beneficial for the yield performance of cauliflower at all the studied water replacement levels.

\section{ACKNOWLEDGMENTS}

To the Coordenação de Aperfeiçoamento de Pessoal de Nível Superior - Brasil (Capes), for the financial support; and the Universidade Estadual de Maringá, for providing the research facilities.

\section{REFERENCES}

ALLEN, R. G.; PEREIRA, L. S.; RAES, D.; SMITH, M. Crop evapotranspiration guidelines for computing crop water requirements. Rome: FAO, 1998.

ALVES, A. U.; PRADO, R. M.; CORREIA, M. A. R.; GONDIM, A. R. O.; CECÍLIO FILHO, A. B.; POLITI, L. S. Couve-flor cultivada em substrato, marcha de absorção de macronutrientes e micronutrientes. Ciência e Agrotecnologia, v. 35, n. 1, p. 45-55, 2011.

BARRETO, R. F.; SCHIAVON JÚNIOR, A. A.; MAGGIO, M. A.; PRADO, R. D. Silicon alleviates ammonium toxicity in cauliflower and in broccoli. Scientia Horticulturae, v. 225, n. 1, p. 743-750, 2017.

CARDOSO, A. I. I.; SILVA, N. Influência do cultivar e do tamanho das sementes na produção de couve-flor. Revista Ceres, v. 56, n. 6, p. 777-782, 2009.

COELHO,A.P.; FARIA, R. T.; DARLI,A.B.; PALARETTI, L. F.; ZANINI, J. R. Clorofilômetro portátil como forma de manejo da irrigação e adubação nitrogenada em aveiabranca. Revista Brasileira de Agricultura Irrigada, v. 12, n. 2, p. 2542-2553, 2018.

COSTA, G. F.; MARENCO, R. A. Fotossíntese, condutância estomática e potencial hídrico foliar em árvores jovens de andiroba (Carapa guianensis). Acta Amazonica, v. 37, n. 2, p. 229-234, 2007.

CURVELO, C. R. S.; FERNANDES, E. F.; DINIZ, L. H. B.; PEREIRA, A. I. A. Desempenho agronômico da couve-flor (Brassica oleracea var. botrytis) em função da adubação silicatada. Revista de Agricultura Neotropical, v. 6, n. 1, p. 87-91, 2019.

EPSTEIN, E.; BLOOM, A. J. Nutrição mineral de plantas: princípios e perspectivas. Londrina: Ed. Planta, 2006.

FERREIRA, A. R.; LIMA JÚNIOR, J. A.; OLIVEIRA, P. D.; AVIZ, W. L. C.; SANTOS, H. C. A. Desempenho produtivo de couve-flor submetida a diferentes manejos de irrigação e doses de boro em ambiente protegido. Revista Engenharia na Agricultura, v. 27, n. 5, p. 440-451, 2019.

FERREIRA, D. F. Sisvar: a computer analysis system to fixed effects split plot type designs. Revista Brasileira de Biometria, v. 37, n. 4, p. 529-535, 2019.

HACHMANN, T. L.; REZENDE, R.; PINTRO, P. T. M.; SAATH, R.; ANJO, F. A.; MENEZES, C. S. L. Yield, antioxidant activity and shelf-life of cauliflower inflorescences under drought stress and foliar spraying of selenium. Ciência e Agrotecnologia, v. 43, e017819, 2019. 
MAY, M.; TIVELLI, S. W.; VARGAS, P. F.; SAMRA, A. G.; SACCONI, L. V.; PINHEIRO, M. Q. A cultura da couve-flor. Campinas: Instituto Agronômico, 2007. (Boletim técnico, 200).

HORTIBRASIL. Normas de identidade, padronização e classificação da couve-flor (Brassica oleracea L. var. botrytis L.) para o programa brasileiro para a melhoria dos padrões comerciais e embalagens de hortigranjeiros. 2011. Available at: http://www.hortibrasil.org.br/ classificacao/couveflor/arquivos/norma.htm. Access on: 14 Mar. 2021.

JADHAO, K. R.; BANSAL, A.; ROUT, G. R. Silicon amendment induces synergistic plant defense mechanism against pink stem borer (Sesamia inferens Walker.) in finger millet (Eleusine coracana Gaertn.). Scientific Reports, v. 10, e4229, 2020.

LOZANO, C. S.; REZENDE, R.; HACHMANN, T. L.; SANTOS, F. A. S.; LORENZONI, M. Z.; SOUZA, Á. H. C. Produtividade e qualidade de melão sob doses de silício e lâminas de irrigação em ambiente protegido. Pesquisa Agropecuária Tropical, v. 48, n. 2, p. 140-146, 2018.

MALAVOLTA, E. Manual de nutrição mineral de plantas. São Paulo: Agronômica Ceres, 2006.

MAROUELLI, W. A. Tensiômetros para o controle de irrigação em hortaliças. Brasília, DF: Embrapa Hortaliças, 2008. (Circular técnica, 57).

MENEGALE, M. L. C.; CASTRO, G. S. A.; MANCUSO, M. A. Silício: interação com o sistema solo-planta. Journal of Agronomic Sciences, v. 4, n. esp., p. 435-454, 2015.

NUNES, A. M. C.; NUNES, L. R. L.; RODRIGUES, A. J. O.; UCHÔA, K. S. A. Silício na tolerância ao estresse hídrico em tomateiro. Revista Cientifica Rural, v. 21, n. 2, p. 239-258, 2019.

OLIVEIRA, F. A.; SANTOS, C. A.; COSTA, E. S. P.; GOULART, R. G. T.; ANDRADE, N. F.; DINIZ, C. S.; CARMO, M. G. F. Desempenho de híbridos de couveflor nas condições da baixada fluminense - RJ. Revista Brasileira de Agropecuária Sustentável, v. 8, n. 1, p. 3036, 2018.

PAULETTI, V.; MOTTA, A. C. V. Manual de adubação e calagem para o estado do Paraná. Curitiba: SBCS/ Nepar, 2017.

PEREIRA, M. E. M.; LIMA JUNIOR, J. A.; LIMA, V. M.; OLIVEIRA, P. D.; SILVA, A. L. P. Viabilidade econômica da produção de couve-flor irrigada por gotejamento no nordeste paraense. Amazonian Journal of Agricultural and Environmental Sciences, v. 61, n. 1, p. 1-8, 2018.

SANTOS, H. G.; JACOMINE, P. K. T.; ANJOS, L. H. C.; OLIVEIRA, V. Á.; LUMBRERAS, J. F.; COELHO, M. R.; ALMEIDA, J. A.; ARAÚJO FILHO, J. C.; OLIVEIRA, J.
B.; CUNHA, T. J. F. Sistema brasileiro de classificação de solos. 5. ed. Brasília, DF: Embrapa, 2018.

SHAMS, A. S.; FARAG, A. A. Implications of water stress and organic fertilization on growth, yield and water productivity of cauliflower (Brassica oleracea var. botrytis L.). Journal of Plant Production, v. 10, n. 10, p. 807-813, 2019.

SILVA, C. B.; SILVA, J. C.; BRANDÃO JUNIOR, W. Q.; DAMASCENO, F. A.; BARBOSA JÚNIOR, M. R.; SANTOS, M. A. L. Teor de clorofila, carotenoides e índice SPAD na alface (Lactuca sativa) em função de lâminas de irrigação e níveis salinos. Ciência Agrícola, v. 18, n. 3, p. 19-22, 2020.

SILVA, F. G.; DUTRA, W. F.; DUTRA, A. F.; OLIVEIRA, I. M.; FILGUEIRAS, L. M. B.; MELO, A. S. Trocas gasosas e fluorescência da clorofila em plantas de berinjela sob lâminas de irrigação. Revista Brasileira de Engenharia Agrícola e Ambiental, v. 19, n. 10, p. 946-952, 2015.

SOHAIL, N. K.; ULLAH, Z.; AHMAD, J.; KHAN, A.; NAWAZ, F.; KHAN, R. Effect of deficit irrigation and nitrogen levels on growth and yield of cauliflower under drip irrigation. Pure and Applied Biology. v. 7, n. 2, p. 910-921, 2018.

SOUZA, C. S.; OLIVEIRA, V. N. S.; SILVA, E. C. A.; FERREIRA, L. M. M.; SILVA, M. J. N.; ARAÚJO, P. C. D. Comportamento de mudas de Bambusa vulgaris Schrad. EX J.C. Wendl submetidas ao estresse hídrico e salino, utilizando água residuária da psicultura. Ciência Agrícola, v. 17, n. 2, p. 7-16, 2019.

SOUZA, L. C.; MELO, N. C.; SIQUEIRA, J. A. M.; SILVA, V. F. A.; OLIVEIRA NETO, C. F. Comportamento bioquímico no milho submetido ao déficit hídrico e a diferentes concentrações de silício. Revista Agrarian, v. 8, n. 29, p. 260-267, 2015.

TAIZ, L.; ZEIGER, E.; MOLLER, I. M.; MURPHY, A. Fisiologia e desenvolvimento vegetal. 6. ed. Porto Alegre: Artmed, 2017.

TORRES, J. L. R.; VALLE, D. X. P.; CUNHA, M. A. Aspectos morfológicos e produtividade da cultivar Sharon de couve-flor cultivada em diferentes solos. Magistra, v. 26, n. 2, p. 124-132, 2014.

VIEIRA, G. H. S.; MANTOVANI, E. C.; SEDIYAMA, G. C.; DELAZARI, F. T. Indicadores morfo-fisiológicos do estresse hídrico para cultura da cana-de-açúcar em função de lâminas de irrigação. Bioscience Journal, v. 30, n. 1 , p. $65-75,2014$.

WEERAHEWA, D.; SOMAPALA, K. Role of silicone on enhancing disease resistance in tropical fruits and vegetables: a review. OUSL Journal, v. 11, n. 1, p. 135162, 2016. 